\title{
A Model for the Growth of Opportunistic Macroalgae (Enteromorpha sp.) in Tidal Estuaries
}

\author{
I. Martins* and J. C. Marques \\ IMAR-Institute of Marine Research, clo Department of Zoology, University of Coimbra, 3004-517 Coimbra, Portugal
}

Received 30th March 2001 and accepted in revised form 25 September 2001

\begin{abstract}
The aim of this work was to develop a model capable of simulating the gross and the net growth of Enteromorpha sp. in tidal estuaries. The model was developed for the Mondego Estuary (Western Portugal) taking into account the key factors that control green macroalgae in the area. Enteromorpha gross growth was defined as a function of light, temperature, salinity and internal nutrients $(\mathrm{N}$ and $\mathrm{P})$. Net growth was defined as gross growth minus respiration. The model was calibrated using a set of experimental data obtained in the laboratory under semi-controlled conditions. Sub-models of tidal height and light extinction coefficient variation were included for predicting macroalgal growth in the field, which constituted the model validation. According to the results, model predictions are well within the observed results, both in the laboratory and in the field. The largest discrepancies between predicted and observed values in the field refer to winter months and July. Possibly at these periods of the year, the prevailing external conditions (very low salinity in winter and high temperature and PFD in July) induced some physiological responses by Enteromorpha, which were not described by the model (e.g. sporulation, desiccation).

The model was also used to demonstrate the need to consider dynamic descriptions of the light extinction coefficient in the water column $(k)$ when assessing primary productivity in tidal environments. If macroalgal-specific (e.g. nutrient internal status) and site-specific parameters (e.g. minimal and maximal depth, photoperiod) are considered, the present model may be used in a broader scale.

(C) 2002 Elsevier Science Ltd. All rights reserved.
\end{abstract}

Keywords: Enteromorpha growth, model, validation, tidal, light extinction coefficient

\section{Introduction}

In the last decade, the occurrence of an excessive growth of green macroalgae has been reported in a significant number of coastal areas (Kolbe et al., 1995; Sfriso, 1995; Morand \& Briand, 1996; Flindt et al., 2000). Most of the works regarding this subject assess the quantification of macroalgal biomass (Lavery et al., 1991; Hernández et al., 1997; Schories et al., 1997), the relationships of macroalgal growth with nutrients (Pedersen \& Borum, 1996; Viaroli et al., 1996) and with other external factors (temperature and photon flux density-Rivers \& Peckol, 1995; precipitation and river management-Martins et al., 2001) or the impacts of their excessive growth (Valiela et al., 1997; Lopes et al., 2000; Pardal et al., 2000) and subsequent decomposition on the surrounding environment (Viaroli et al., 1992; Neira \& Rackemann, 1996). Although some works presented mathematical formulations of macroalgal population dynamics, growth and productivity (Ferreira \& Ramos, 1989; Duarte \& Ferreira, 1993; Bendoricchio et al., 1993, 1994; Duarte, 1995; Solidoro et al., $1997 a, b$; Duarte \& Ferreira, 1997), there is still a lack

\footnotetext{
^E-mail: imjb@mail.telepac.pt
}

in scientific tools capable of integrating knowledge about macroalgal processes as a way of predicting their growth and productivity in coastal areas.

The aim of this work was to build a mathematical model able to predict Enteromorpha growth rates in the Mondego Estuary, taking into consideration previous studies about the factors and processes which control opportunistic macroalgal growth in the system.

\section{Methods}

\section{Study site and previous studies}

The Mondego Estuary (Western Portugal) consists of two different arms, north and south, separated by an alluvium-formed island (Murraceira Island) (Figure 1). Large accumulations of Enteromorpha spp. (mostly E. intestinalis and E. compressa) are more frequent in the inner area of the south arm (Pardal et al., 2000). During high tide, the depth in the south arm ranges between 2 and $4 \mathrm{~m}$ and tidal range varies between 1 and $3 \mathrm{~m}$. Due to siltation in its upstream section, the water circulation in this arm is mostly dependent on the tides and on the freshwater input from the Pranto River (Marques et al., 1993; 


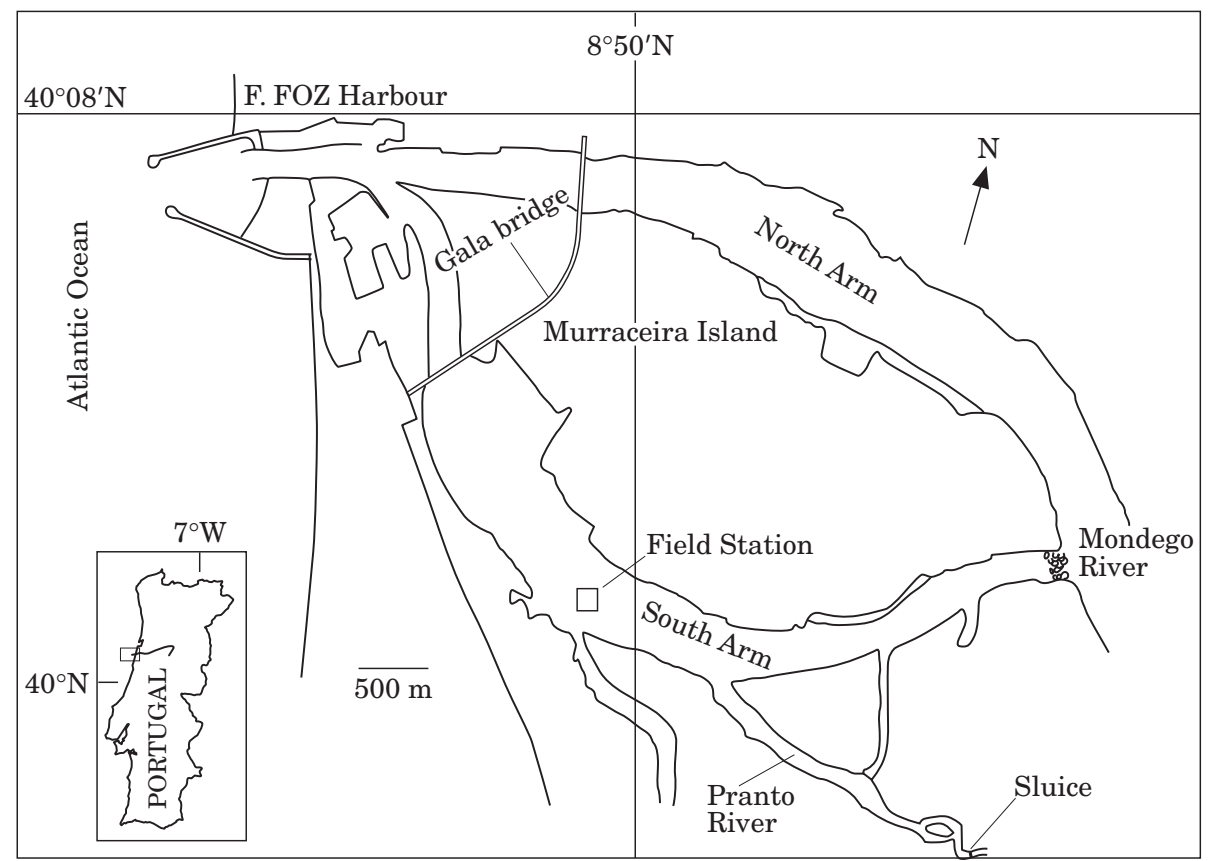

Figure 1. The Mondego Estuary with location of the field station in the inner area of the south arm of the estuary.

Flindt et al., 1997). Freshwater discharge is regulated according to the water needs in the rice crop of the Pranto Valley (Martins et al., 2001). For a more detailed characterization of the system see also Flindt et al. (1997), Pardal et al. (2000), Martins et al. (2001).

During the last decade the south arm of the Mondego Estuary has been almost continuously monitored with respect to environmental factors (Marques et al., 1997; Lillebø et al., 1999a; Pardal et al., 2000; Martins et al., 2001), primary producers (Lillebø et al., 1999b; Martins et al., 1999, 2001; Pardal et al., 2000) and consumers (Múrias et al., 1996; Martins et al., 1997; Lillebø et al., 1999a; Lopes et al., 2000; Pardal et al., 2000).

Previous studies with local Enteromorpha intestinalis (Martins et al., 1999) showed that its growth varies along a bell-shaped curve with salinity and that the optimum salinity range for growth is $18-22$. Nevertheless, E. intestinalis is more affected by lower than by higher salinity (Martins et al., 1999). In the Mondego Estuary, Enteromorpha spp. biomass is usually significantly reduced in winter but in early spring, macroalgal growth starts to enhance (Pardal et al., 2000). However, there are significant year-to-year differences in the yearly standing crop of Enteromorpha spp. (Martins et al., 2001). At the system level, it was concluded that Enteromorpha biomass depends on hydrodynamics, which in turn controls salinity, $\mathrm{N}: \mathrm{P}$ ratios, current velocities and light-extinction coefficients within the system (Martins et al., 2001).

\section{Data for model calibration and validation}

Data used to calibrate the model were obtained from the previously mentioned experiments, where the net growth of Enteromorpha intestinalis $(\mathrm{N}=5)$ was quantified along different salinity gradients in the laboratory (Martins et al., 1999). E. intestinalis growth was estimated from wet weight variations assuming exponential growth. Daily measurements of temperature, salinity and photon flux density were taken and, at the beginning of each experiment, nutrients $\left(\mathrm{NH}_{4}-\mathrm{N}\right.$ and $\left.\mathrm{PO}_{4}-\mathrm{P}\right)$ were added to water in such a concentration that macroalgal growth was never limited. Experimental time was on average 6 days. For more details see Martins et al. (1999).

The model validation was achieved by comparing the predicted Enteromorpha growth rates with Enteromorpha net growth rates estimated in the inner area of the south arm of the Mondego Estuary (Figure 1). From January 1996 to January 1997, one growth experiment was carried out every month with an approximate duration of 20 days (Martins et al., 2001). In each experiment the weight variation (initial and final weight) of 20 replicates $(\mathrm{N}=20)$ was used to estimate Enteromorpha net growth assuming exponential growth. In the field, macroalgal replicates were kept inside experimental devices, which were designed 
to allow light penetration, water circulation inside and to prevent macroinvertebrates from entering. This experimental procedure was previously described in Martins et al. (2001).

\section{Model formulation}

Main processes and state variables. Enteromorpha gross growth $\left(G_{\text {growth }}\right)$ is described as a function of maximum growth rate at the optimum temperature $\left(\mu_{\max }\right)$, light $(f(I))$, temperature $(f(T))$, salinity $(f(S))$ and internal concentration of nutrients $(f(N P))$ :

$$
G_{\text {growth }}=\mu_{\max } \times f(I) \times f(T) \times f(S) \times f(N P)
$$

Macroalgal net growth $\left(N_{\text {growth }}\right)$ is defined by the difference between gross growth $\left(G_{\text {growth }}\right)$ and respiration $(\operatorname{Res} p)$ :

$$
N_{\text {growth }}=G_{\text {growth }}-\operatorname{Res} p
$$

Respiration is considered temperature dependent by an Arrhenius function

$$
\operatorname{Res} p=R_{\max _{20}} \times \theta^{(T-20)}
$$

$R_{\text {max }_{20}}$ - maximum respiration rate at $20^{\circ} \mathrm{C}, \theta-$ empirical coefficient.

The model state variables are Enteromorpha internal nitrogen $\left(N_{\text {int }}\right)$ and internal phosphorus $\left(P_{\text {int }}\right)$ concentrations:

$$
\begin{gathered}
\frac{\partial N_{i n t}}{\partial t}=\psi_{N O 3, N H 4}-\gamma_{N} \\
\frac{\partial P_{i n t}}{\partial t}=\psi_{P O 4}-\gamma_{P}
\end{gathered}
$$

$\psi$ - uptake of nutrients (described by equation 12), $\gamma$ - consumed nutrients (described by equation 13).

Forcing functions. The light harvesting efficiency of algae is influenced by light intensity, temperature and nutrients (Duarte, 1995). Therefore, all these factors were considered as model forcing functions $(f(I)$, $f(T), f(N, P))$. Moreover, due to the dependency of Enteromorpha growth on salinity evidenced from the work of several authors (e.g. Martins et al., 1999; Kamer \& Fong, 2000, 2001), salinity $(f(S))$ was also considered as a forcing function of the model.

Light. Enteromorpha is photoinhibited by high photon flux densities (Häder et al., 1999), thus Steele's photoinhibition relationship (in EPA, 1985) was used to describe the effect of light on Enteromorpha growth:

$$
f(I)=\frac{I}{I s} \times e^{\left(1-\frac{I}{I s}\right)}
$$

$I$ - photon flux density that reaches Enteromorpha surface, Is - optimal photon flux density for photosynthesis.

Temperature. According to experimental evidence (e.g. Poole \& Raven, 1997), the effect of temperature on Enteromorpha growth follows an optimum curve, which may be described by the following expression (Lehman et al., in EPA, 1985):

$$
f(T)=\exp \left[-2 \cdot 3 \times\left(\frac{T-T_{o p t}}{T_{x}-T_{o p t}}\right)^{2}\right]
$$

$T_{x}=T_{\text {min }}$ for $T \leq T_{o p t}$ and $T_{x}=T_{\text {max }}$ for $T>T_{o p t}, T_{o p t}$ optimum temperature at which growth rate is maximum, $T_{\min }$ - lower temperature limit below which growth ceases, $T_{\max }$ - upper temperature limit above which growth ceases.

Salinity. The best fit with the real variation of Enteromorpha intestinalis growth rates vs salinity according to the results of Martins et al. (1999) was obtained with modified Najarian \& Harlem (1975) and Harlem et al. (1977) (in EPA, 1985) expressions.

For salinity $\geq 5$ :

$$
f(S)=1-\left(\frac{S-S_{o p t}}{S_{x}-S_{o p t}}\right)^{m}
$$

$S_{x}=S_{\min }$ and $m=2.5$ for $S<S_{\text {opt }}, S_{x}=S_{\max }$ and $m=2$ for $S \geq$ Sopt

For salinity $<5$ :

$$
f(S)=\frac{S-S_{\min }}{S_{o p t}-S_{\min }}
$$

$S_{o p t}$ - optimum salinity at which growth rate is maximum, $S_{\text {min }}$ - lower salinity limit at which growth rate ceases, $S_{\max }$ - upper salinity limit at which growth ceases.

Nutrients. The dependency of Enteromorpha growth on nutrients was described according to 'Liebig's law of the minimum' (in EPA, 1985), which assumes that only the nutrient in shortest supply limits macroalgal growth. Considering that the optimum interval for the internal $\mathrm{N}: \mathrm{P}$ ratio of Enteromorpha is $12-16$ 
(Björnsäter \& Wheeler, 19890), the dependency of Enteromorpha growth on the internal ratio of nutrients was described by:

$$
\begin{gathered}
\text { If } \mathrm{N}: \mathrm{P} \geq 12 \text { and } \mathrm{N}: \mathrm{P} \leq 16: f(N P)=1 \\
\text { If } \mathrm{N}: \mathrm{P}<12: f(N P)=f(N) \\
\text { If } \mathrm{N}: \mathrm{P}<16: f(N P)=f(P)
\end{gathered}
$$

Nitrogen. Experimental evidence (e.g. Björnsäter \& Wheeler, 1990; Lavery \& McComb in Solidoro et al., 1997a) supports the idea that the dependency of green macroalgae (e.g. Entermorpha spp., Ulva spp.) growth on internal nitrogen concentration $\left(N_{i n t}\right)$ can be defined by an hyperbolic function of the type:

$$
f(N)=\frac{N_{i n t}-N_{i \min }}{k q+N_{i n t}-N_{i \text { min }}}
$$

$N_{i \text { min }}$ - minimum cell quota or subsistence quota for nitrogen, $k q$ - nitrogen half-saturation constant for growth limitation.

Phosphorus. Chlorophyte macroalgae, like Ulva and Enteromorpha, have a considerably lower (less than $20 \%$ ) internal phosphorus concentration than that of nitrogen (Björnsäter \& Wheeler, 1990). Additionally, their phosphorus internal variability seems to occur within a narrow range $\left(1-5 \mathrm{mg} \mathrm{P} \mathrm{g}^{-1} \mathrm{dw}\right.$ ) (Solidoro et al., 1997a). For such reasons, some authors prefer to model the dependency of chlorophyte growth only on external phosphorus and through Monod kinetics (e.g. Solidoro et al., 1997a,b).

However, the work of Björnsäter and Wheeler (1990) suggests that chlorophyte growth depends on internal phosphorus by a linear relationship. This approach was followed in the present model and defined by equations 11 . The existence of a maximum internal phosphorus concentration $\left(P_{i \text { max }}\right)$ is considered, even if experimental evidence suggests that such a concentration is seldom reached (Björnsäter \& Wheeler, 1990).

$$
\begin{gathered}
\text { If } P_{i n t}<P_{i \max }: f(P)=\frac{P_{i n t}}{P_{i \text { max }}} \\
\quad \text { If } P_{\text {int }} \geq P_{i \text { max }}: f(P)=1
\end{gathered}
$$

\section{Uptake and consumption of nutrients}

As previously described in equations 4 and 5, the variation of internal nutrient concentrations ( $\mathrm{N}$ and $\mathrm{P}$ ) is defined by the uptake of nutrients $(\psi)$ minus consumed nutrients $(\gamma)$.
The uptake of nutrients by Enteromorpha is generically defined by:

$$
\psi_{X}=\frac{X_{i \max }-X_{i n t}}{X_{i \max }-X_{i \min }} \star \frac{V_{\text {max }} \star X_{\text {ext }}}{K_{x}+X_{\text {ext }}}
$$

$X_{i n t}$ - internal nutrient concentration, $X_{i \text { max }}$ - maximum internal concentration of nutrient, $X_{i}$ min minimum internal concentration of nutrient, $V_{\max }-$ maximum uptake rate of nutrient, $K_{x}$ - half-saturation constant for the uptake of nutrient, $X_{\text {ext }}$ - external concentration of nutrient. In turn, the amount of consumed nutrients depends on macroalgal growth rate, which is generically described by:

$$
\gamma_{X}=X_{\text {int }}{ }^{\star} G_{\text {growth }}
$$

$X_{i n t}$ - internal nutrient concentration, $G_{\text {growth }}$ - gross growth rate.

\section{Sub-models for tidal height and light variation with depth}

Tidal movements in estuaries regulate the depth of immersion of ephemeral macroalgae (Henley \& Ramus, 1989). Depth variation caused by tide follows a sinusoidal pattern, which may be described by a generic sinusoidal expression:

$$
\text { depth }=a+b \star \sin \frac{2 \pi t+c}{T_{i}}
$$

where $a=\frac{d_{h t}+d_{l t}}{2}, b=\frac{d_{h t}-d_{l t}}{2}$ and

$$
c=\frac{T_{i}}{2 \pi} \times \arcsin \left(\frac{d_{\left(t_{0}\right)}-a}{b}\right)
$$

$d_{h t}$ - maximum depth, $d_{l t}$ - minimum depth, $d_{t 0}$ - depth at time $=0, T_{i}$ - time interval between high and low water.

The variation of light (as photon flux densityPFD)(I) with depth ( $z$ ) was described through Beer's law (e.g. Parsons et al., 1990):

$$
I_{z}=I_{0} \times e^{-k z}
$$

$I_{O}$ - PFD at the water surface, $k$ - light extinction coefficient.

The Geophysics Institute of the University of Coimbra provided data on total daily irradiation and daily photoperiod. Daily values of photon flux density at the surface $\left(I_{0}\right)$ were calculated from total daily irradiation during the study period following the methodology described in Ferreira and Ramos (1989), which assumes that the visible fraction (400$750 \mathrm{~nm}$ ) of total irradiation energy corresponds to a 


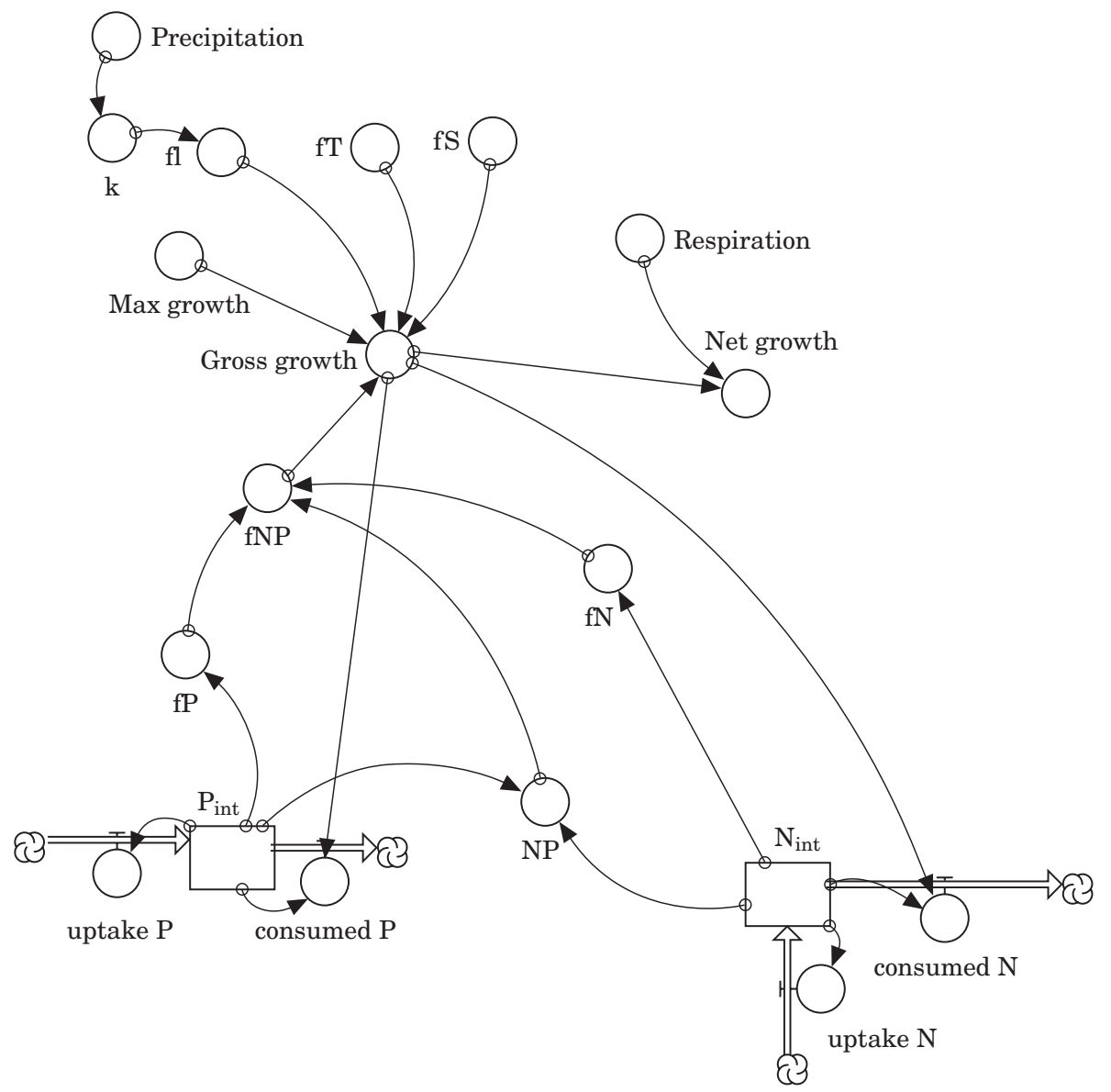

FIGURE 2. Simplified STELLA diagram of the model. State variables: internal nitrogen concentration $\left(N_{\text {int }}\right)$ and internal phosphorus concentration $\left(P_{\text {int }}\right)$. Forcing functions: light limitation factor $(f(l))$, temperature limitation factor $(f(T))$, salinity limitation factor $(f(S))$ and nutrient limitation factor $(f(N P))$.

reduction of $58 \%$ of the total and that, consequently, only $42 \%$ of the overall energy are available for photosynthesis. Additionally, due to losses related to the angle of incidence of sun and wind stress on the water surface, an average decrease of $15 \%$ in the total irradiation was also considered (Ferreira \& Ramos, 1989; Parsons et al., 1990). Furthermore, an additional reduction of $48 \%$ in total irradiation corresponding to losses related with sediment settling on the surface of experimental cages where Enteromorpha individuals were kept was also considered. This value was based on experimental measurements (Martins, unpublished). Photoperiod duration was also considered to estimate daily PFD.

In aquatic systems, primary production also depends on the light extinction coefficient of the water column $(k)$. In estuaries, this coefficient presents significant daily and seasonal variations (Ferreira \& Ramos, 1989; Kirk in Vergara et al., 1997). Daily variations of $k$ are caused mainly by tides and are characterized by important increases of $k$ during ebb and flood due to re-suspension of bottom sediments (e.g. Vergara et al., 1997). In the Mondego Estuary, the seasonal variations of $k$ depends mainly on river flow variations, which in turn depends both on precipitation and river management practices (Martins et al., 2001).

To account for seasonal variations, $k$ was defined by two different expressions (equations 16.1 and 16.2) depending on precipitation. The model also accounts for daily variations of $k$ through $k$-dependency on depth, which varies daily with tidal movements (equation 14). Equations 16.1 and 16.2 are based on real measurements obtained in the Mondego Estuary by the author.

$$
\begin{aligned}
\text { If precipitation } & <3 \mathrm{~mm}: \\
k & =4.5984 \times e^{-1.0935 \times \text { depth }} \\
\text { If precipitation } & \geq 3 \mathrm{~mm}: \\
k & =10.853 \times e^{-1.3753 \times \text { depth }}
\end{aligned}
$$

precipitation is expressed as daily precipitation. 


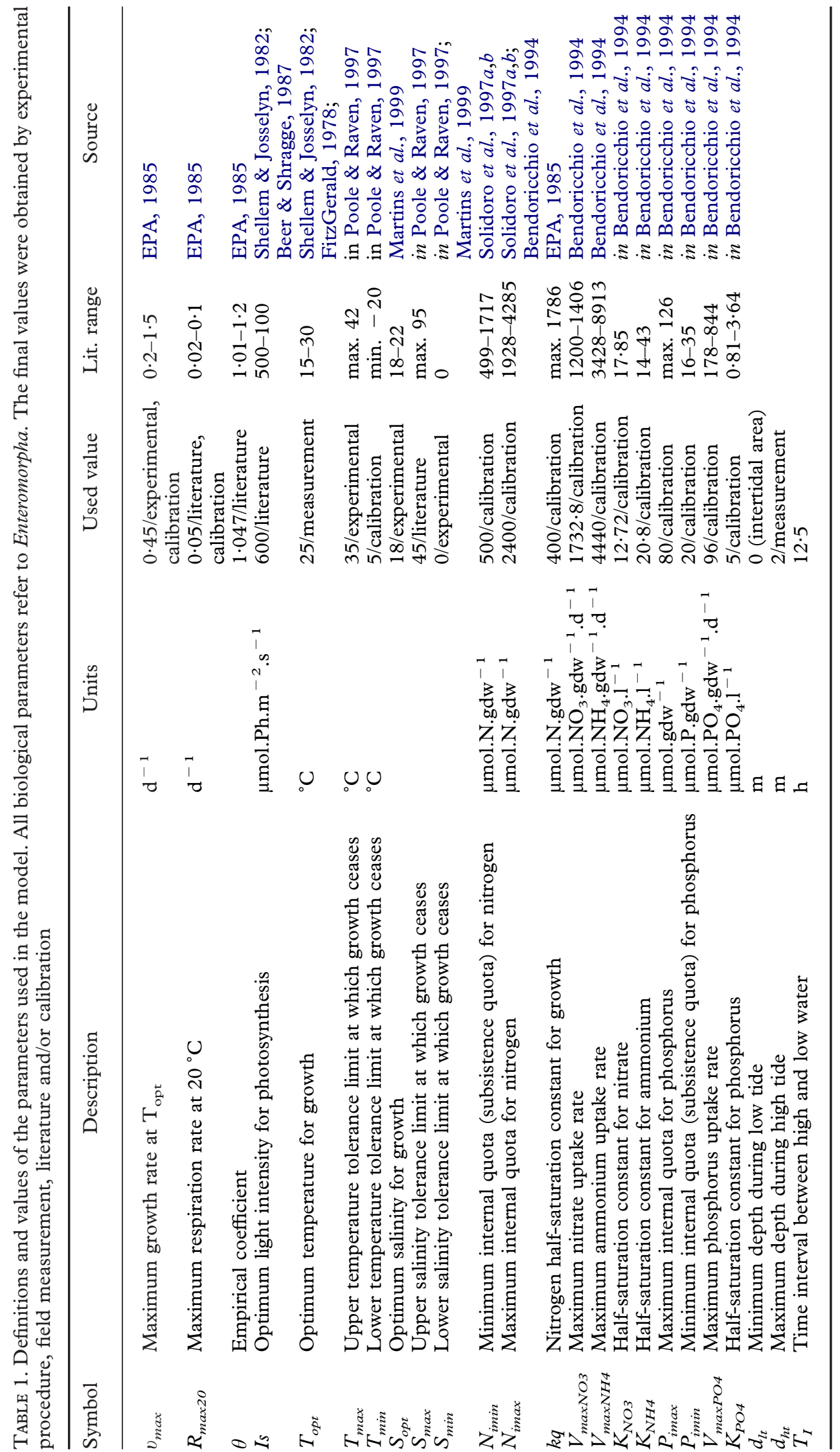



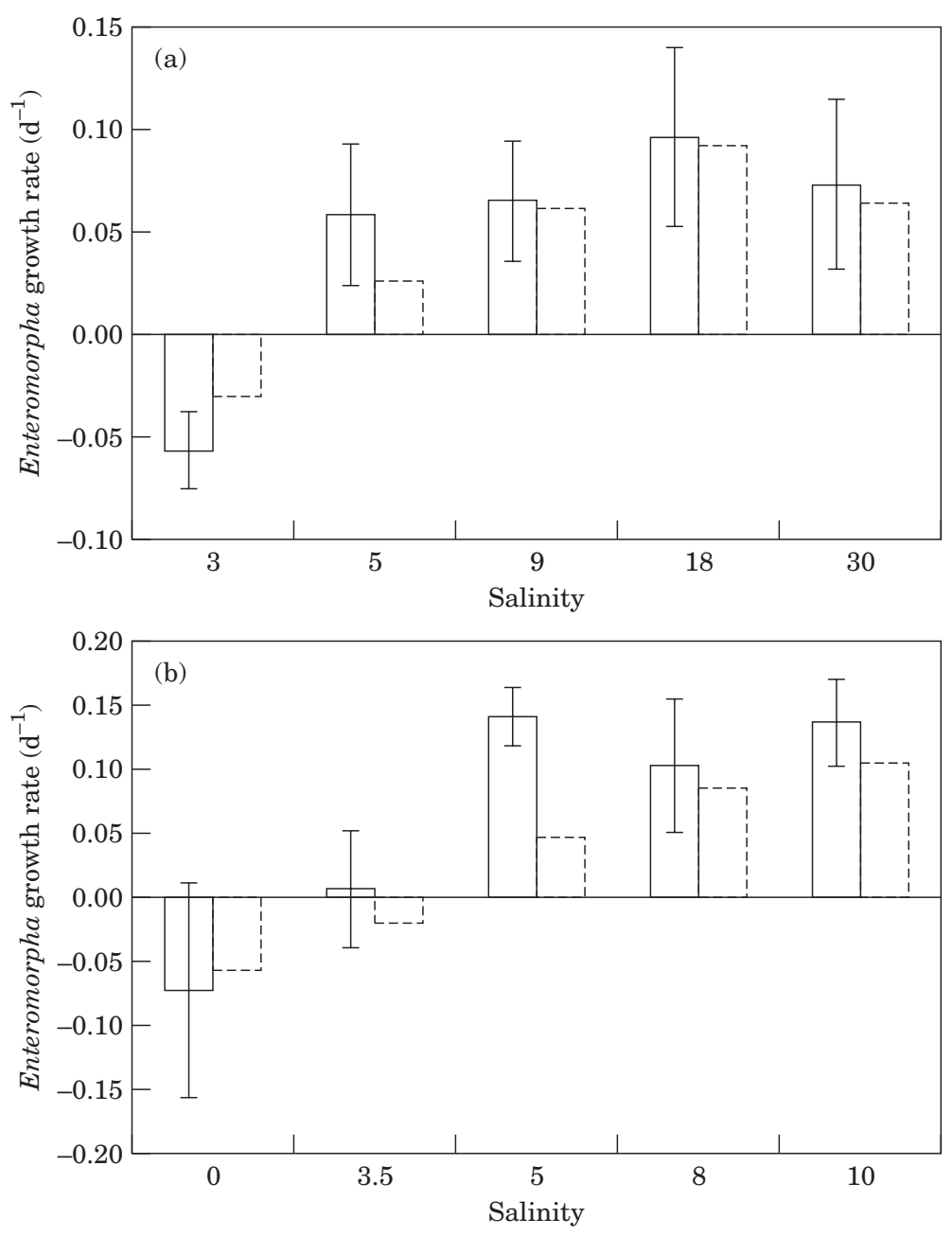

FIGURE 3. Observed net growth rates \pm standard error $(\mathrm{N}=5)$ versus predicted net growth rates of Enteromorpha intestinalis $\left(\mathrm{d}^{-1}\right)$ estimated in the laboratory at 2 different experiments: (a) within a salinity range of $0-30$; (b) within a salinity range of $0-10$. Experiment (a) and (b) were run at different times of the year under different natural light conditions. $\square$ Observed, Predicted.

The model was run with STELLA 5.0 software using a time step of approximately $1 \mathrm{~h}(1 \cdot 2 \mathrm{~h})$ for approximately 13 months (397 days). The conceptual diagram of the model is shown in Figure 2 and parameter values are shown in Table 1 .

\section{Results}

Model predictions for the variations of Enteromorpha intestinalis net growth with salinity were well within the observed results obtained in the laboratory under semi-controlled conditions [Figures 3(a) and (b)]. Except for macroalgal growth at a salinity of five in the second experiment [Figure 3(b)], all the predicted values are within the standard error bars of the observed growth rates. Additionally, the Model IIregression between observed and simulated values
(Sokal \& Rolf, 1995; Duarte, 1995; Macedo et al., 1998 ) is significant (ANOVA, $P-0 \cdot 001$ ). The intercept of the regression is not significantly different from 0 and the slope is not significantly different from 1 , which highlights the good fitting level between observed and predicted values (Figure 4).

Results from validation suggest that the model is able to predict the yearly vartiations in the net growth of Entermorpha in the Mondego Estuary (Figure 5). However, in winter and July there are larger discrepancies between observed and simulated results. Although in winter, both the observed and the simulated macroalgal growth rates were negative, which is in accordance with the prevailing external conditions, the observed growth rates were much lower than the simulated ones (Figure 5, values in the legend). Additionally, the model did not predict the negative 




FIGURE 4. Model II regression between observed and predicted net growth rates of Enteromorpha intestinalis ( $\mathrm{d}^{-1}$ ) for calibration results (observed values obtained under laboratory conditions). The regression is significant (ANOVA, $P<0 \cdot 001)$.

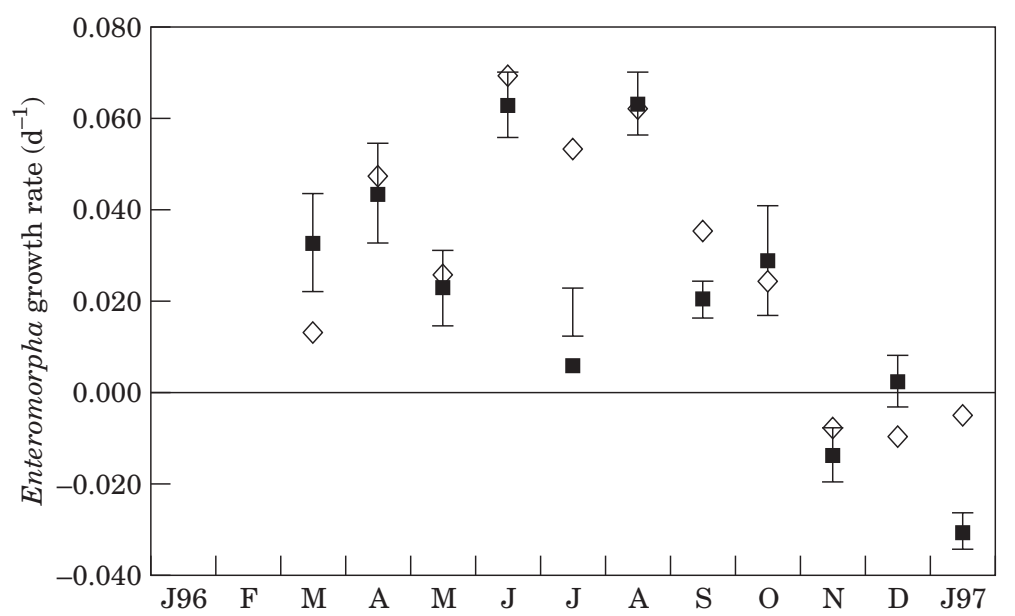

FIGURE 5. Observed net growth rates \pm standard error $(\mathrm{N}=20)$ versus predicted net growth rates of Enteromorpha $\left(\mathrm{d}^{-1}\right)$ estimated in the south arm of the Mondego estuary. Real/simulated values of January $1996\left(-0 \cdot 33 /-0 \cdot 023 \mathrm{~d}^{-1}\right)$ and February $1996\left(-0 \cdot 18 / 0 \cdot 008 \mathrm{~d}^{-1}\right)$ are not shown. $\mathbf{0 b s e r v e d ;} \diamond$ Predicted.

growth of Enteromorpha observed in July. Nevertheless, considering the rest of the months, almost $70 \%$ of the predicted values are within the observed macroalgal growth rates (average \pm standard error) (Figure 5).

To assess for the effects of using a dynamic description of the light extinction coefficient $(k)$ or considering a constant $k$, the model standard simulation (where $k$ is precipitation- and depth-dependent) was compared with a simulation using a constant value of $k\left(k=2.76 \mathrm{~m}^{-1}\right)$ based on real values (Martins, unpublished). According to the results (Figure 6), Enteromorpha growth is considerably lower when $k$ is described as a constant value, especially during spring, summer and autumn. In winter the results from both simulations show similar values.

\section{Discussion}

The model seems capable of predicting Enteromorpha sp. net growth rates close to real values. Nevertheless, predicted growth rates were closer to real ones for data obtained in the laboratory than for field values. This is explained by the higher number of random effects and processes which occur in the field compared to laboratory experiments. Some of these processes (e.g. decay/leaching, sporulation, desiccation) may be related with the occurrence of the largest differences between predicted and observed results during winter and July. Future model approaches on this matter should thus try to describe these processes and the factors that regulate them. The level of importance of such processes may however vary from system to 


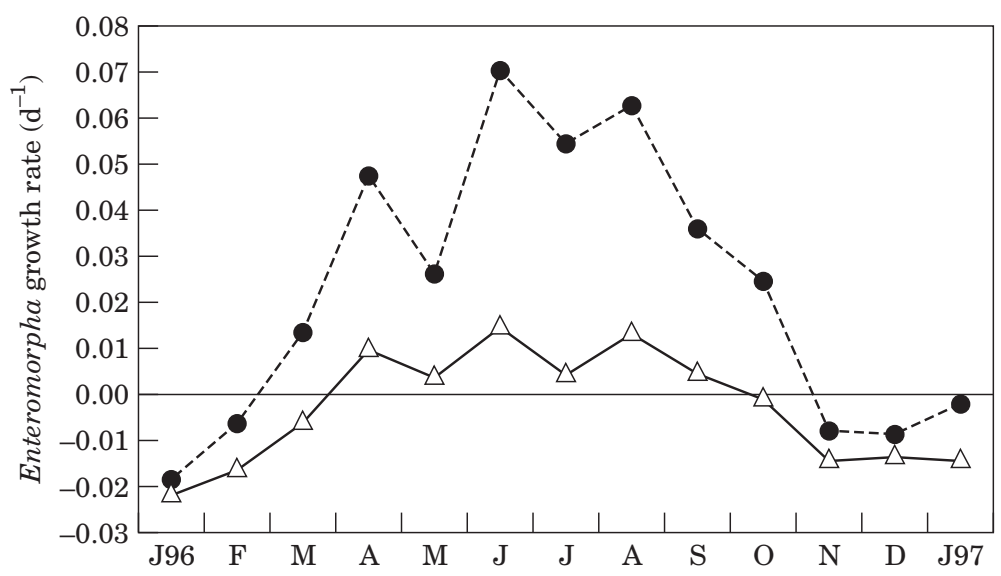

Figure 6. Predicted variation of the net growth rate of Enteromorpha using a dynamic description of $k$ and using a constant value of $k$ (see text for explanation). Dynamic description of $k ; \triangle$ Constant $k$.

system according to natural and geographic characteristics of each system. In the case of systems where summer temperatures and PFD can be high, such as the Mondego Estuary, desiccation stress may be an important process related to the summer decline of macroalgal populations (e.g. Rivers \& Peckol, 1995; Hernández et al., 1997).

The present model was deliberately built to predict only Enteromorpha net growth, defined as gross growth minus respiration. Although many other processes (e.g. herbivory, advective transport) are important to the final balance of Enteromorpha productivity in the Mondego Estuary, the model was only developed to predict macroalgal net growth, in part because reliable quantification of these rates in the field are not easily done. On the other hand, net growth rates of Enteromorpha obtained in the field do not correspond exclusively to macroalgal gross growth minus respiration. In fact, although experimental cages were built to prevent grazers from entering (Martins et al., in press), it was not possible to exclude completely the presence of small grazers. This aspect may have contributed to the larger differences between predicted and observed growth rates of Enteromorpha in the field compared with results obtained in the laboratory.

Contrary to previous models of primary productivity in tidal systems (e.g. Solidoro et al., 1997a,b), the present model uses a dynamic-description of the light extinction coefficient in the water column $(k)$ and demonstrates that such approach generates more accurate results than the previous one. According to the present model, the use of a constant $k$ (which was based on a real measurement in the Mondego Estuary) underestimates the growth rate of Enteromorpha sp. This is explained by the fact that, although during ebb and flood $k$ increases assumes low values even during high tide, which is related with shallowness of the south arm of the Mondego Estuary. The importance of using an accurate description of the light extinction, both due to its great variations in tidal systems and its importance to primary production levels (Ferreira \& Ramos, 1989), is thus highlighted by these results. In the case of the Mondego Estuary, the seasonal variations of $k$ are not only dependent on precipitation but also on river management (Martins et al., 2001). Although it is not easy to establish a mathematical formulation between $k$ and river management practices, the description of $k$-variation in the south arm of the estuary may still be improved.

Ultimately, the present model may be understood as the sub-model for the net growth of Enteromorpha, which will be integrated in a wider model for the Mondego Estuary. Apart from describing Enteromorpha net growth, the new model will also account for other processes (e.g. herbivory, macroalgal transport mechanisms) which are important to the final balance of green macroalgal productivity in the Mondego Estuary.

\section{Acknowledgements}

The Portuguese Foundation for Science and Technology (FCT) supported this work through a $\mathrm{PhD}$ grant attributed to I. Martins (PRAXIS XXI/ $\mathrm{BD} / 3744 / 94)$.

The authors wish to thank Dr Alves from the Geophysics Institute for providing irradiance data, to Pedro Duarte for critical reading of the manuscript and suggestions, to João Gomes Ferreira and Maria Fiolmena Macedo for discussion and suggestions. 


\section{References}

Beer, S. \& Shragge, B. 1987 Photosynthetic carbon metabolism in Enteromorpha compressa (Chlorophyta). Fournal of Phycology 23, 580-584.

Bendoricchio, G., Coffaro, G. \& Di Luzio, M. 1993 Modelling the photosynthetic efficiency of Ulva rigida growth. Ecological Modelling 67, 221-232.

Bendoricchio, G., Coffaro, G. \& De Marchi, C. 1994 A trophic model for Ulva rigida in the Lagoon of Venice. Ecological Modelling 75/76, 485-496.

Björnsäter, B. R. \& Wheeler, P. A. 1990 Effect of nitrogen and phosphorus supply on growth and tissue composition of Ulva fenestrata and Enteromorpha intestinalis (Ulvales, Chlorophyta). Fournal of Phycology 26, 603-611.

Duarte, P. \& Ferreira, J. G. 1993 A methodology for parameter estimation in seaweed productivity modelling. Hydrobiologia 260/ 261, 183-189.

Duarte, P. 1995 A mechanistic model of the effects of light and temperature on algal primary productivity. Ecological Modelling 82, 151-160.

Duarte, P. \& Ferreira, J. G. 1997 A model for the simulation of macroalgal population dynamics and productivity. Ecological Modelling 98, 199-214.

EPA (Environmental Protection Agency, USA) 1985 Rates, constants, and kinetics. Formulations in surface water quality modelling, 2nd Edition, $455 \mathrm{pp}$.

Ferreira, J. G. \& Ramos, L. 1989 A model for the estimation of annual production rates of macrophyte algae. Aquatic Botany 33, 53-70.

Fitzgerald, W. J. 1978 Environmental parameters influencing the growth of Enteromorpha clathrata (Roth) J. Ag. in the intertidal zone on Guam. Botanica Marina 21, 207-220.

Flindt, M. R., Kamp-Nielsen, L., Marques, J. C., Pardal, M. A., Bocci, M., Bendoricchio, G., Salomonsen, J., Nielsen, S. N. \& Jørgensen, S. E. 1997 Description of the three shallow estuaries: Mondego River (Portugal), Roskilde Fjord (Denmark) and the Lagoon of Venice (Italy). Ecological Modelling 102, 17-31.

Häder, D. P., Lebert, M., Jiménez, C., Salles, S., Aguilera, J., Flores-Moya, A., Mercado, J., Viñegla, B. \& Figueroa, F. L. 1999 Pulse amplitude modulated fluorescence in the green macrophytes, Codium adherens, Enteromorpha muscoides, Ulva gigantea and Ulva rigida, from the Atlantic coast of Southern Spain. Environmental Experimental Botany 41, 247-255.

Henley, W. J. \& Ramus, J. 1989 Photoacclimation and growth rate responses of Ulva rotundata (Chlorophyta) to intraday variations in growth irradiance. Fournal of Phycology 25, 398-401.

Hernández, I., Peralta, G., Pérez-Lloréns, J. L., Vergara, J. J. \& Niell, F. X. 1997 Biomass and dynamics of growth of Ulva species in Palmones River Estuary. Fournal of Phycology 33, 764-772.

Kamer, K. \& Fong, P. 2000 A fluctuating salinity regime mitigates the negative effects of reduced salinity on the estuarine macroalga, Enteromorpha intestinalis (L.) Link. Fournal of Experimental Marine Biology and Ecology 254, 53-69.

Kamer, K. \& Fong, P. 2001 Nitrogen enrichment ameliorates the negative effects of reduced salinity on the green macroalga Enteromorpha intestinalis. Marine Ecology Progress Series 218, 87-93.

Kolbe, K., Kaminski, E., Michaelis, H., Obert, B. \& Rahmel, J. 1995 Macroalgal mass development in the Wadden Sea: first experiences with a monitoring system. Helgolander Meeresuntersuchungen 49, 519-528.

Lavery, P. S., Lukatelich, R. J. \& McComb, A. J. 1991 Changes in the biomass and species composition of macroalgae in a eutrophic estuary. Estuarine, Coastal and Shelf Science 33, 1-22.

Lillebø, A. I., Pardal, M. \& Marques, J. C. $1999 a$ Population structure, dynamics and production of Hydrobia ulvae (Pennant) (Mollusca: prosobranchia) along an eutrophication gradient in the Mondego estuary (Portugal). Acta Oecologica 20, 289-304.
Lillebø, A. I., Flindt, M. R., Pardal, M. A. \& Marques, J. C. 19996 The effect of macrofauna, meiofauna and microfauna on the degradation of Spartina maritime detritus from a salt marsh area. Acta Oecologica 20, 249-258.

Lopes, R. J., Pardal, M. A. \& Marques, J. C. 2000 Impact of macroalgae blooms and wader predation on intertidal macroinvertebrates-Experimental evidence in the Mondego estuary (Portugal). Fournal of Experimental Marine Biology and Ecology 249, 165-179.

Macedo, M. F., Ferreira, J. G. \& Duarte, P. 1998 Dynamic behaviour of photosynthesis-irradiance curves determined from oxygen production during variable incubation periods. Marine Ecology Progress Series 165, 31-43.

Marques, J. C., Maranhão, P. \& Pardal, M. A. 1993 Human impact assessment on the subtidal macrobenthic community structure in the Mondego Estuary (Western Portugal). Estuarine, Coastal and Shelf Science 37, 403-419.

Marques, J. C., Pardal, M. A., Nielsen, S. N. \& Jørgensen, S. E. 1997 Analysis of the properties of energy and biodiversity along an estuarine gradient of eutrophication. Ecological Modelling 102, 155-167.

Martins, I., Marques, J. C., Jørgensen, S. E. \& Nielsen, S. N. 1997 Modelling the effects of macroalgae blooms on the population dynamics of Cyathura carinata (Crustacea: Isopoda) in a eutrophied estuary. Ecological Modelling 102, 33-53.

Martins, I., Oliveira, J. M., Flindt, M. R. \& Marques, J. C. 1999 The effect of salinity on the growth rate of the macroalgae Enteromorpha intestinalis (Chlorophyta) in the Mondego estuary (west Portugal). Acta Oecologica 20, 259-265.

Martins, I., Pardal, M. A., Lillebø, A. I., Flindt, M. R. \& Marques, J. C. 2001 Hydrodynamics as a major factor controlling the occurrence of green macroalgal blooms in a eutrophic estuary: A case study on the influence of precipitation and river management. Estuarine, Coastal and Shelf Science 52, 165-177.

Morand, P. \& Briand, X. 1996 Excessive growth of macroalgae: a symptom of environmental disturbance. Botanica Marina 39, 491-516.

Múrias, T., Cabral, J. A., Marques, J. C. \& Goss-Custard, J. D. 1996 Short-term effects of intertidal macroalgal blooms on the macrohabitat selection and feeding behaviour of wading birds in the Mondego estuary (West Portugal). Estuarine, Coastal and Shelf Science 43, 677-688.

Neira, C. \& Rackemann, M. 1996 Black spots produced by buried macroalgae in intertidal sandy sediments of the Wadden Sea: effects on the meiobenthos. Fournal of Sea Research 36, 153-170.

Pardal, M. A., Marques, J. C., Metelo, L., Lillebø, A. I. \& Flindt, M. R. 2000 Impact of eutrophication on the life cycle, population dynamics and production of Amphithoe valida (Amphipoda) along an estuarine spatial gradient (Mondego estuary, Portugal). Marine Ecology Progress Series 196, 207-219.

Parsons, T. R., Takahashi, M. \& Hargrave, B. 1990 Biological Oceanographic Processes, 3rd Edition, Pergamon Press. 330 pp.

Pedersen, M. F. \& Borum, J. 1996 Nutrient control of algal growth in estuarine waters. Nutrient limitation and the importance of nitrogen requirements and nitrogen storage among phytoplankton and species of macroalgae. Marine Ecology Progress Series 142, 261-272.

Poole, L. J. \& Raven, J. A. 1997 The biology of Enteromorpha. Progress and Physics Research 12 (Round, F. E. \& Chapman, D. J., eds). Biopress Ltd, $123 \mathrm{pp}$.

Rivers, J. \& Peckol, P. 1995 Summer decline of Ulva lactuca (Chlorophyta) in a eutrophic embayment: interactive effects of temperature and nitrogen availability? Fournal of Phycology 31, 223-228.

Schories, D., Albrecht, A. \& Lotze, H. 1997 Historical changes and inventory of macroalgae from Konigshafen Bay in the northern Wadden Sea. Helgolander Meeresuntersuchungen 51, 321-341.

Sfriso, A. 1995 Temporal and spatial responses of growth of Ulva rigida C. Ag. To environmental and tissue concentrations of nutrients in the Lagoon of Venice. Botanica Marina 38, 557-573. 
Shellem, B. H. \& Josselyn, M. N. 1982 Physiological ecology of Enteromorpha clathrata (Roth) Grev. on a salt marsh mudflat. Botanica Marina 25, 541-549.

Solidoro, C., Pecenik, G., Pastres, R., Franco, D. \& Dejak, C. 1997 a Modelling macroalgae (Ulva rigida) in the Venice Lagoon: model structure identification and first parameters estimation. Ecological Modelling 94, 191-206.

Solidoro, C., Brando, V. E., Dejak, C., Franco, D., Pastres, R. \& Pecenik, G. $1997 b$ Long term simulations of population dynamics of Ulva $r$. in the lagoon of Venice. Ecological Modelling 102, 259-272.

Sokal, R. R. \& Rohlf, F. J. 1995 Biometry, 3rd Edition, Freeman Press, New York, $887 \mathrm{pp}$.

Valiela, L., McClelland, J., Hauxwell, J., Hersh, D. \& Foreman, K. 1997 Macroalgal blooms in shallow estuaries: controls and ecophysiological and ecosystem consequences. Limnological Oceanography 42, 1105-1118.

Vergara, J. J., Pérez-Lloréns, J. L., Peralta, G., Hernández, I \& Niell, F. X. 1997 Seasonal variation of photosynthetic performance and light attenuation in Ulva canopies from Palmones River Estuary. Fournal of Phycology 33, 773-779.

Viaroli, P., Pugnetti, A. \& Ferrari, I. 1992 Ulva rigida growth and decomposition processes and related effects on nitrogen and phosphorus cycles in a coastal lagoon (Sacca di Goro, Po River Delta). Proceedings of the 25th EMBS (Colombo, G. et al., eds). Olsen \& Olsen, Denmark, 77-84.

Viaroli, P., Bartoli, M., Bondavalli, C., Christian, R. R., Giordani, G. \& Naldi, M. 1996 Macrophyte communities and their impact on benthic fluxes of oxygen, sulphide and nutrients in shallow eutrophic environments. Hydrobiologia 329, 105-119. 